\title{
DYNAMICS OF AGRICULTURAL EXPANSION IN AREAS OF THE BRAZILIAN SAVANNA BETWEEN 2000 AND 2019
}

\author{
P. R. M. Pereira ${ }^{1}$, E. L. Bolfe ${ }^{1,2 *}$, T. C. S. Rodrigues ${ }^{3}$, E. E. Sano \\ ${ }^{1}$ University of Campinas - Unicamp, Campinas - SP, Brazil. p.roberto18@hotmail.com \\ ${ }^{2}$ Brazilian Agricultural Research Corporation - Embrapa, Campinas - SP, Brazil. edson.bolfe@embrapa.br \\ ${ }^{3}$ Maranhão State University - Uema, São Luís - MA, Brazil. taissageo@ hotmail.com \\ ${ }^{4}$ Brazilian Agricultural Research Corporation - Embrapa, Planaltina - DF, Brazil. edson.sano@embrapa.br
}

\section{Commission III, WG III/7}

KEY WORDS: Agricultural Mapping, Cerrado Biome, Geobia, Land Use and Land Cover.

\begin{abstract}
:
The information survey and the land use and land cover (LULC) change monitoring are essential to understand the changes in the landscape and their impacts on the environment. The Brazilian savanna (Cerrado) constitutes the second largest biome in Brazil and is highly relevant because of its rich biodiversity. The Cerrado in the Maranhão State is facing a high conversion rate of its natural vegetation into agricultural systems because of the agricultural development policies. This article aims to analyze and quantify the LULCC in the Chapadinha microregion, Maranhão State, Brazil, by comparing Landsat satellite images from 2000, 2009 , and 2019. The Chapadinha microregion covers an area of more than $14,000 \mathrm{~km}^{2}$ and, since 2000 , presents significant spatial transformations related to agricultural expansion. The goal of this expansion is the economic development based on agricultural commodities (mainly soybean monoculture) for exportation. The study area is the third microregion in terms of agricultural production in Maranhão. The satellite image interpretation showed a reduction of more than $800 \mathrm{~km}^{2}$ of natural vegetation.
\end{abstract}

\section{INTRODUCTION}

Since 1970s, the Cerrado biome has consolidated as the main region of the country in terms of expansion of the agricultural because of the favorable climate and soil, and the large amount of land available for cultivation. As a result, Brazil is one of the largest grain producers and exports in the world, with emphasis on soy production. Cerrado occupies approximately $20 \%$ of the Brazilian territory $\left(\sim 2\right.$ million $\left.\mathrm{km}^{2}\right)$ and is distributed in the states of Goiás, Tocantins, Mato Grosso, Mato Grosso do Sul, Minas Gerais, Bahia, Maranhão, Piauí, Rondônia, Paraná, São Paulo, and the Federal District (Sano et al., 2009).

The combined influence of climate (highly seasonal), topography (flat or steep, depending on the location), and soils (highly weathered, deep, and acidic) controls the formation of different grass-, shrub-, and tree-dominated phytophysiognomies with varying proportions of these three strata. Cerrado has more than 12 thousand cataloged plant species - approximately 40\% are endemic (MMA, 2015), therefore, it is included as one of world's hotspots for biodiversity conservation. In the same time, it is considered the last agricultural frontier in the country (Klink and Machado, 2005). Government incentives and private capital associated with the Cerrado Development Plan (Santos, 2011) increased the suppression of natural vegetation and the implementation of large-scale production of agricultural commodities (Inocêncio e Calaça, 2009).

In Maranhão, the Cerrado occurs from southern portion to the north, covering $64 \%$ of its territory $\left(74,288 \mathrm{~km}^{2}\right)$. Recent natural vegetation suppression in this state is associated with Prodecer III project that started in the Gerais de Balsas microregion in the 1990s. Soybean cultivation in the Maranhão started in 2000s, when agricultural frontier began to shift from western Bahia State to the east of Maranhão. The emphasis was in the Chapadinha and Baixo Parnaíba microregions, considered as the Cerrado's new agricultural frontier (Gaspar, 2010, Santos, 2011, Campos, 2011). In the 2000s, the study area presented the first agricultural modernization process with the insertion of the monoculture crop. Its consolidation started in 2003 with emphasis on the municipalities of Brejo and Buriti, since they present landscape characteristics favorable to the development of highly mechanized agriculture in flat terrains, regardless of dominant well-drained, low fertility Oxisols developed from pre-weathered sediments of the Barreiras Formation. In addition, the prices of lands are still relatively low (Guimarães, 2012).

The use of computer tools and remote sensing techniques to survey characteristics of the region of interest are highly relevant to define and implement biodiversity conservation strategies, reduction of environmental impacts, and environmentally sustainable agriculture planning (Bendini et al., 2016, Sano et al. 2019a). The Brazilian savanna is a key region in terms of expansion and consolidation of the national agricultural development and the applications of remote sensing for analysis of monitoring agriculture, land use and land cover is very important for the region (Arantes et al. 2016, Bolfe et al. 2016, Silva et al., 2016, Picoli et al., 2018, Araújo, et al. 2019, Camargo et al., 2019, Alencar et al., 2020).

This paper aims to analyze the dynamics of land use change in the Chapadinha microregion, Maranhão State, by identifying and quantifying the land use dynamics during the 2000-2018 period. This study also relates the historical and socioeconomic activities with the processes of transformations and their impacts.

\footnotetext{
${ }^{*}$ Corresponding author
} 


\section{MATERIALS AND METHODS}

\subsection{Study Area}

The Chapadinha microregion occupies approximately 10,400 $\mathrm{km}^{2}$ in the northeast of Maranhão State. It encompasses the municipalities of Anapurus, Belágua, Buriti, Brejo, Chapadinha, Mata Roma, Milagres do Maranhão, São Benedito do Rio Preto, and Urbano Santos (Figure 1)

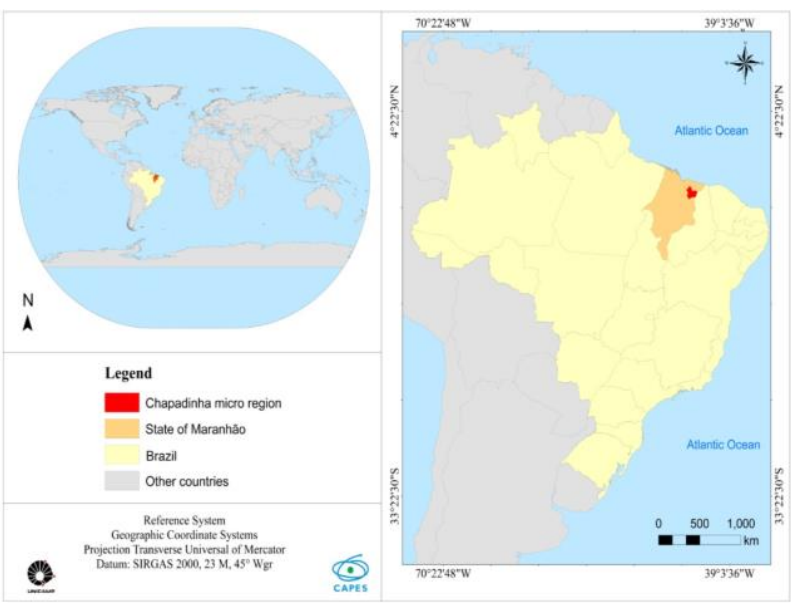

Figure 1. Location of the Chapadinha microregion in the Maranhão State. Source: adapted from IBGE (2019).

IBGE (2019) found 219,617 inhabitants in Chapadinha in 2010, an increase of $22 \%$ in relation to the Demographic Census conducted in 2000 . Approximately $45 \%$ of the population have been living in rural areas. The microregion of interest showed significant growth (138\%) of urban population in the 2000-2010 period. Regardless of presence of high-tech, mechanized agriculture that represents more than $80 \%$ of the current production model in the area, the majority of population still survive based on extractivism, agriculture practiced in itinerant way (cutting, slashing, and burning), low-productivity cattle ranching and fishing.

The study area is located in a transition region between the Cerrado and Caatinga biomes (Batistella et al., 2013). There is predominance of arboreal forest formations belonging to the Cerrado domain, mixed forest, and extensive fields of open vegetation in tabular zones. The microregion presents high temperatures and annual rainfall ranging between $800 \mathrm{~mm}$ and $1200 \mathrm{~mm}$, and humidity ranging between $70 \%$ and $80 \%$. It presents two distinct climate periods, a rainy season and a dry season, differentiated landscapes with high vegetation variety, depending on the seasonality (Reschke, 2013).

The initial human occupation in the study area is strongly associated with the extensive cattle ranching. Since 1990s, the Chapadinha microregion integrates the state's agricultural production chain, with large-scale soy production (Gaspar, 2010). According to Almeida (2017), the process is directly associated with the improvement of plant and soil management technologies. In fact, this improvement boosted local production and productivity of soybean for exportation and agroforestry for cellulose, causing large suppression of natural vegetation cover.

According to data provided by the Municipal Agricultural Production (PAM) (IBGE, 2019), soybean is responsible for $85 \%$ of the total area of croplands. Other crops found in the study area are rice, corn, and cassava. Data from IBGE showed that, there were 411 hectares of soybean in 2000 , increasing to 65,240 hectares in 2018. The intensification of agricultural production is observed since 2002, when the area destined for soybean cultivation increased from 550 hectares to 3,716 hectares in 2003. The production increased from 1,320 tons to more than 8,900 tons (Figure 2).

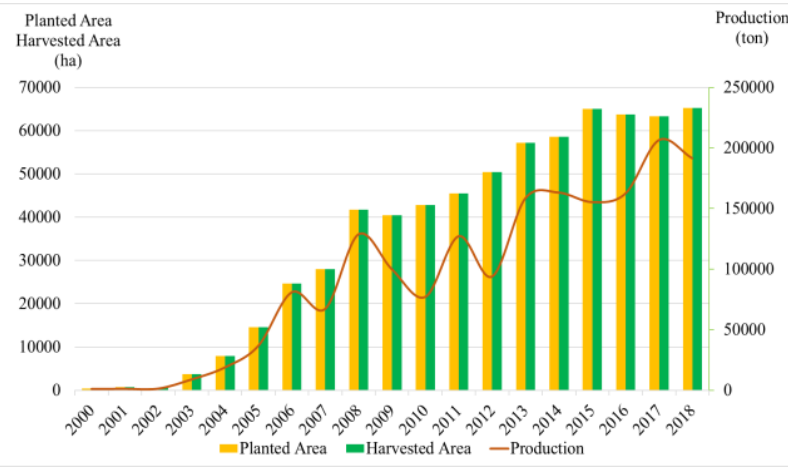

Figure 2. Evolution of areas destined for agricultural production from 2000 to 2018 in the Chapadinha microregion.

Source: IBGE (2019).

\subsection{Images}

The LUCL mapping was carried out based on visual interpretation of a set of Landsat satellite images from 2000 to 2019. The images were downloaded from the United States Geological Survey Earth Explorer Platform (USGS, 2020). The selected images were from August to December, with less than $5 \%$ of cloud cover (Table 1 ).

\begin{tabular}{|c|c|c|c|c|}
\hline Year & Path/Row & Overpass & $\begin{array}{c}\text { Spectral } \\
\text { Bands }\end{array}$ & $\begin{array}{c}\text { \% } \\
\text { Cloud } \\
\text { Cover }\end{array}$ \\
\hline \multirow{3}{*}{2000} & $219 / 62$ & $28 / 08 / 2000$ & & \\
& $219 / 63$ & $28 / 08 / 2000$ & & \\
& $220 / 62$ & $22 / 10 / 2000$ & $1,2,3,4$ & \\
\hline \multirow{3}{*}{2009} & $220 / 63$ & $22 / 10 / 2000$ & and 5 & \\
& $219 / 62$ & $08 / 10 / 2009$ & (Landsat- & \\
& $219 / 63$ & $09 / 11 / 2009$ & 5 TM) & \multirow{2}{*}{$<5 \%$} \\
& $220 / 62$ & $29 / 09 / 2009$ & & \\
& $220 / 63$ & $29 / 09 / 2009$ & & \\
& $219 / 62$ & $18 / 09 / 2019$ & $2,3,4,5$, & \\
& $219 / 63$ & $18 / 09 / 2019$ & 6 and 7 & \\
& $220 / 62$ & $09 / 09 / 2019$ & (Landsat- & \\
& $220 / 63$ & $04 / 05 / 2009$ & 8 OLI) & \\
\hline
\end{tabular}

Table 1. Characteristics of the Landsat images selected for land use and land cover mapping. Source: USGS (2020).

The database contained 12 layers (four scenes in three periods) of each image, formed in the TerraView software (INPE, 2017). The following digital image processing tasks were performed: i) registration, radiometric transformations, and visual adjustments, ii) generation of the normalized difference vegetation index (NDVI), iii) image segmentation and extraction of attributes, iv) data mining and image classification based on the decision tree algorithm, and v) analysis of the results.

\subsection{Image Processing}

To minimize the atmospheric influence, the images were preprocessed. Initially, the gray level digital numbers were converted into radiance and then to the surface reflectance following the methodology described by Ponzoni and Shimabukuro (2009) and using the Spring 5.6 software. For the 
conversion of Landsat-5 images, we used the equations described by Rosa (2009) (Eq. 1).

$$
\mathrm{L}=\left(\frac{\text { LMAX }- \text { LMIN }}{\text { Qcalmax }- \text { Qcalmin }}\right) *(\text { Image })+\operatorname{LMIN} \lambda
$$

where $\quad \mathrm{L}=$ the spectral radiance recorded by the sensor $\left[\mathrm{W} / \mathrm{m}^{2} \mathrm{sr} \mu \mathrm{m}\right]$ Qcal $=$ calibrated pixel value $[\mathrm{DN}]$

Qcalmin $=$ minimum $\mathrm{DN}$ value corresponding to $\operatorname{LMIN} \lambda[\mathrm{DN}]$

Qmax = maximum $\mathrm{DN}$ value corresponding to $\operatorname{LMAX} \lambda[\mathrm{DN}]$

$\operatorname{LMIN} \lambda=$ spectral radiance recorded by the sensor that is scaled in relation to Qcalmin [W/ $/ \mathrm{m}^{2} \mathrm{sr} \mu \mathrm{m}$ ]

LMAX $\lambda=$ spectral radiance recorded in the sensor that is scaled in relation to Qcalmax [W/m $\left.\mathrm{m}^{2} \mathrm{sr} \mu \mathrm{m}\right]$.

The radiance at the top of the atmosphere was calculated from the function described by Ponzoni and Shimabukuro (2009) (Eq. 2):

$$
p \lambda=\frac{\pi * L \lambda}{E \lambda * \cos (z) * d \mathrm{r}}
$$

where $\quad d r=$ inverse of the square of the Earth-Sun relative distance in astronomical units

$\mathrm{z}=$ zenital solar angle (degrees) at the time of image acquisition

$\mathrm{E} \lambda=$ average solar irradiance at the top of the atmosphere $\left(\mathrm{mW} / \mathrm{cm}^{2} . \Omega . \mu \mathrm{m}\right)$

$\mathrm{L} \lambda=$ monochromatic spectral radiance $\left(\mathrm{W} / \mathrm{m}^{2} . \mathrm{sr} . \mu \mathrm{m}\right)$

$\rho \lambda=$ monochromatic reflectance.

For the calculation of radiance and reflectance of the Landsat- 8 images, we observed changes in the conversion parameters, showing a multiplicative factor and an additive factor calculated separately and following Eq. 3:

$\rho \lambda^{\prime}=\mathrm{M}^{*} \mathrm{Qcal}+\mathrm{A}$

where $\quad \rho \lambda^{\prime}=$ spectral reflectance

Qcal = image to be transformed

$\mathrm{M}=$ multiplicative factor for the reflectance of the band to be converted

$\mathrm{A}=$ additive factor for the reflectance of the band to be converted.

The images had the process of atmospheric correction to minimize the effects of atmospheric scattering. The dark-object subtraction technique of multispectral data - DOS (Chaves, 1988) was applied using the QGIS software through the SemiAutomatic Classification Plugin (Congedo, 2016).

Based on radiance and reflectance values, the NDVI was obtained as a tool for monitoring plant vigor, since NDVI is sensitive to green biomass variation, chlorophyll content, and water stress (Sano et al., 2019b). Its calculation based on the relationship between the red and near infrared bands (4).

$$
\mathrm{NDVI}=\frac{(\mathrm{PNIR}-\mathrm{PR})}{(\mathrm{PNIR}+\mathrm{PR})}
$$

where $\quad$ NDVI $=$ normalized difference vegetation index

$\mathrm{P}_{\mathrm{NIR}}=$ near infrared band

$\mathrm{P}_{\mathrm{R}}=$ red band

\footnotetext{
${ }^{1}$ Similarity threshold / area 10/100 was established for Landsat 5, and for Landsat $850 / 300$, following the parameters described in Meneses and Almeida (2012).
}

After the conversion, a histogram contrast was applied. It consists of the pixel scattering process with a linear function of 1 being applied, without changes in the original spectral characteristics of the targets (Meneses and Almeida, 2012). The images were clipped to the boundaries of the Chapadinha microregion provided by IBGE (2019). We then generated a merged image with all multispectral bands and NDVI. The metafile was elaborated in the TerraView image visualization software.

The images were also segmented and classified by using the Geographic Data Mining Analyst (GeoDMA) platform (Korting et al., 2009). It integrates methods of image analysis with data mining techniques from spatial and spectral information, functioning as a TerraView plug-in (Korting et al., 2009).

\subsection{Segmentation, Attribute Extraction, and Sample Collection}

Image segmentation consists of a process of grouping pixels having similar characteristics in discrete and contiguous regions without intersecting themselves and constituting in segments (objects). We used segmentation by growing regions (Baatz and Schape, 2000), which, according to Benz et al. (2004), is a technique of pixel aggregation that starts with a pixel (seed), predefined values of similarity ${ }^{1}$, threshold, and scale, grouping neighbors having similar properties and considering the spectral and spatial characteristics in the composition of objects (Zanotta et al., 2019).

After the segmentation process, attributes related to the relational objects present in the image and associated with spatial (13) and spectral (15) characteristics were extracted, resulting in a total of 28 attributes for each scene or 112 attributes for each image. This step was performed using the Geodma plug-in available in the TerraView ${ }^{\mathrm{TM}}$ 5.3.3 software.

Six LULC classes were defined: Field, Forest, Bare Soil, Agricultural Areas, Water, Built Area. At least 68 sampling points were collected for each LULC class, according to the methodology proposed by Sano et al. (2009).

\subsection{Classification and Validation}

This step was performed by Geodma. We used the decision tree procedure (Korting et al., 2009) created by the classification algorithm C5.0 for classifying and mapping LULC classes. The results were obtained based on the visual interpretation of the images and definition of LULC classes according to the technical manual proposed by IBGE (2009).

The process starts with the definition of hierarchy of data by internal nodes and leaves connected by branches. Each node corresponds to a variable that is used for classification. The first node is known as the root, and the others are called intermediate. The leaves correspond to the variables related to the classes that each intermediate node is associated (Korting et al., 2009).

Initially, three decision trees were created, aiming to identify trees that presented a lower branching pattern and better performance, allowing their use for all images. For this purpose, the Kappa and the performance indices were used as the validating model to classify the maps generated. The maps were analyzed and compared with the thresholds established by Landis and Koch (1977). 


$$
k=\frac{n * \sum d p-\Sigma(l * c)}{n^{2}-\sum(l * c)}
$$

where $\mathrm{k}=$ index value

$\mathrm{n}=$ total number of samples

$\Sigma \mathrm{dp}=$ sum of the main diagonal

$\Sigma\left(l^{*} c\right)=$ product of the sum of the row by the columns of each representative class.

Kappa index was evaluated considering the following categories: Very Bad $=<0.00, \mathrm{Bad}=0.00-0.20$, Regular $=0.21-0.40$, Good $=0.41-0.60$, Very Good $=0.61-0.80$, and Excellent $=0.81-1.00$.

To validate the classifications, a cross combination was carried out with ground truth data and GeoEye images that are available for free in the Google Earth platform. The following satellite overpasses were selected: December 30, 2000, April 23, 2009, and May 22, 2019, in jpeg format, using 122 points for the year 2000 classification, 114 points for the year 2009 , and 165 points for 2019. They were created using the random points available in the QGIS 2.18.8 software.

\subsection{Change Detection}

After correcting the errors associated with the classification, the vector data related to land cover classes were converted into matrix information using conversion tools available in the QGIS 2.18.8 software. The purpose here was to perform change detection analysis and to generate transition matrices among the mapped classes. Thus, the Molusce (Modules for Land Use Change Simulations) alteration detection statistics available in the QGIS were applied. The results generated tables with information on the class area and frequency of coverage, besides reference matrices related to the years 2000 to 2009 , and to the years 2009 to 2019. The results identified a percentage of the loss and gain rates between the classes.

\section{RESULTS}

\subsection{Validation of the Classification}

LULC changes, as well as to identify the advance of deforestation in the Cerrado associated with the advance of the agricultural frontier in 2000, 2009, and 2019. The Landsat satellite images allowed the mapping of the main patterns of land cover changes. The validation of the classification models was performed using the confusion matrix and the Kappa index.

The overall accuracy rate were $76 \%, 67 \%$ and $59 \%$ respectively for the years 2000, 2009 and 2019. The forest class hit were 77\%, $87 \%$, and $72 \%$, and the agricultural areas were $87 \%, 88 \%$, and $88 \%$ for the classified classes. It is worthwhile to mention the low hit rate for the silviculture $(17 \%, 8 \%$, and $28 \%)$, with a high rate of confusion with the forest and agricultural areas. This relatively high rate of confusion is possibly associated with climatic of drought during the acquisition of the analyzed images and the natural conditions of cerrado, as expected in the naturally heterogeneous cerrado (Alencar et al., 2020).

Kappa index values ranged from good to very good. Images from the years 2000, 2009 and 2019 presented Kappa indices of 0.708 , 0.603 , and 0.519 , respectively. The results showed efficiency of the classification elaborated from data mining. The level of confusion was high, mainly for the year $2019^{2}$. Tables 2,3 , and 4 show the confusion matrices elaborated to generate the Kappa index.

\begin{tabular}{|c|c|c|c|c|c|c|c|c|}
\hline & \multicolumn{7}{|c|}{ Classification } \\
\hline Reference & Fl & Fd & Ac & Sc & Ex & W & Ot & B \\
\hline Fl & 23 & & & & & & & \\
\hline Fd & 5 & 28 & 3 & & 8 & 2 & & \\
\hline Ac & 2 & & 8 & & 2 & 2 & & \\
\hline Sc & 2 & & & 4 & & & & \\
\hline Ex & & & & & 11 & 2 & & \\
\hline W & & & & & 1 & 10 & & \\
\hline Ot & & & & & & & 0 & \\
\hline B & & & & & & & & 9 \\
\hline
\end{tabular}

Table 2. Confusion matrix for year 2000.

\begin{tabular}{|c|c|c|c|c|c|c|c|c|}
\hline \multirow{2}{*}{ Reference } & \multicolumn{7}{|c|}{ Classification } \\
\hline & Fl & Fd & Ac & Sc & Ex & W & Ot & B \\
\hline Fl & 22 & 3 & & & & & & \\
\hline Fd & 6 & 17 & 3 & & 5 & 2 & & \\
\hline Ac & 2 & 3 & 15 & & 4 & 2 & & \\
\hline Sc & 2 & & & 4 & & & & \\
\hline Ex & & & & & 6 & 2 & & \\
\hline W & 1 & & & & 2 & 4 & & \\
\hline Ot & & & & & & & 0 & \\
\hline B & & & & & & & & 9 \\
\hline
\end{tabular}

Table 3. Confusion matrix for year 2009 .

\begin{tabular}{|c|c|c|c|c|c|c|c|c|}
\hline \multirow{2}{*}{ Reference } & \multicolumn{7}{|c|}{ Classification } \\
\cline { 2 - 10 } & Fl & Fd & Ac & Sc & Ex & W & Ot & B \\
\hline Fl & 21 & & & & & & & \\
\hline Fd & 8 & 13 & 3 & & 8 & 2 & & \\
\hline Ac & 2 & 6 & 17 & & 7 & 2 & & \\
\hline Sc & 8 & 3 & 1 & 17 & & & & \\
\hline Ex & & 2 & 12 & & 11 & 2 & & \\
\hline W & & & & & 1 & 10 & & \\
\hline Ot & & & & & & & 0 & \\
\hline B & & & & & & & & 9 \\
\hline
\end{tabular}

Table 4. Confusion matrix for year 2019.

\subsection{Land Use and Land Cover}

The generation of thematic LULC maps allowed the mapping and quantifying transition rates, in addition to the analysis of agricultural expansion in the area. Table 5 and Figures 3, 4, and 5 show the LULC classes as well as their quantification in net values and relative frequency for years 2000, 2009, and 2019.

\begin{tabular}{|c|c|c|c|c|c|c|}
\hline Classes & $\begin{array}{c}\mathbf{2 0 0 0} \\
\left(\mathbf{K m}^{\mathbf{2}}\right)\end{array}$ & $\begin{array}{c}\mathbf{2 0 0 0} \\
\mathbf{( \% )}\end{array}$ & $\begin{array}{c}\mathbf{2 0 0 9} \\
\left(\mathbf{K m}^{2}\right)\end{array}$ & $\begin{array}{c}\mathbf{2 0 0 9} \\
(\mathbf{\%})\end{array}$ & $\begin{array}{c}\mathbf{2 0 1 9} \\
\left(\mathbf{K m}^{2}\right)\end{array}$ & $\begin{array}{c}\mathbf{2 0 1 9} \\
(\mathbf{\%})\end{array}$ \\
\hline Fl & 6617.48 & 63.38 & 6145.44 & 58.94 & 5755.28 & 55.34 \\
\hline Fd & 3523.81 & 33.75 & 3253.99 & 31.21 & 3388.43 & 32.58 \\
\hline Ac & 68.86 & 0.66 & 664.17 & 6.37 & 872.65 & 8.39 \\
\hline Sc & 24.47 & 0.23 & 67.41 & 0.65 & 251.57 & 2.42 \\
\hline Ex & 99.26 & 0.95 & 126.43 & 1.21 & 37.78 & 0.36 \\
\hline W & 51.73 & 0.50 & 69.52 & 0.67 & 55.03 & 0.53 \\
\hline Ot & 41.16 & 0.39 & 78.20 & 0.75 & 15.14 & 0.15 \\
\hline B & 14.33 & 0.14 & 21.38 & 0.21 & 24.73 & 0.24 \\
\hline
\end{tabular}

Table 5. Changes in the land use and land cover changes in the Chapadinha microregion.

\footnotetext{
${ }^{2} \mathrm{Fl}=$ Forest, $\mathrm{Fd}=$ Fields, $\mathrm{Ac}=$ Agricultural Areas, $\mathrm{Sc}=$ Silviculture,
} $\mathrm{Ex}=$ Bare Soil, $\mathrm{W}=$ Water, $\mathrm{Ot}=$ Others, and $\mathrm{B}=$ Built Areas . 
We can observe the temporal advance of agriculture over natural areas (grasslands and forests), mainly in the eastern portion (municipalities of Brejo, Buriti, and Anapurus), and silviculture in the northern portion (Urbano Santos municipality).

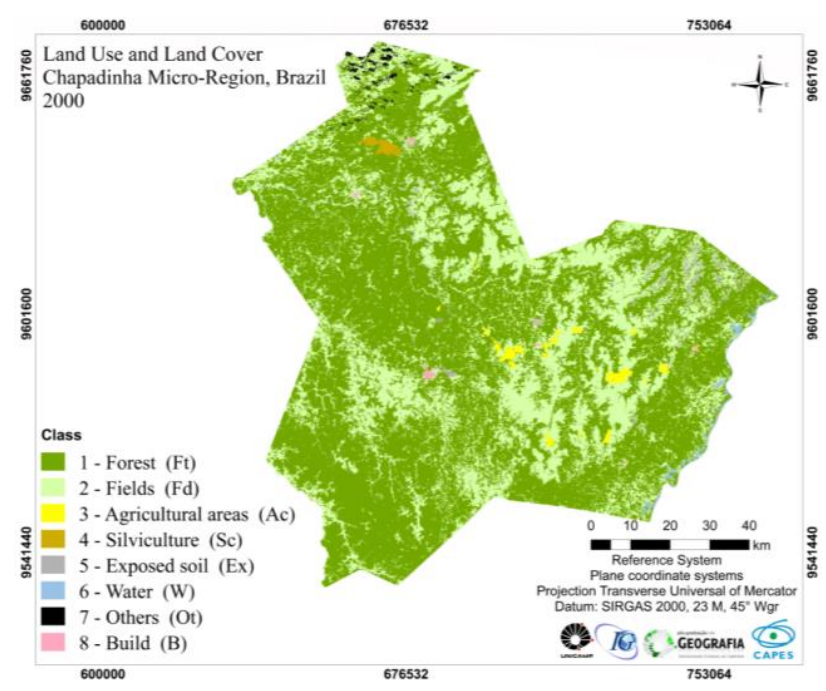

Figure 3. Land use and land cover map of the Chapadinha microregion (year: 2000).

The main changes observed in the area are related to agricultural expansion over the areas of natural vegetation, with a gradual reduction in the areas of forest and grasses. In 2000, these classes represented $6617.48 \mathrm{~km}^{2}$ and $3523.81 \mathrm{~km}^{2}$, respectively. In 2019 , they were reduced to $5755.28 \mathrm{~km}^{2}$ and $3388.43 \mathrm{~km}^{2}$, that is, a reduction of approximately $863 \mathrm{~km}^{2}$ of forested areas, and 135 $\mathrm{km}^{2}$ of grass-dominated areas.

Along the period, a significant increase occurred in new agricultural and forestry areas in the Chapadinha microregion. The data showed an increase of more than $800 \%$ between in the 2000-2019 period. This was boosted mainly by state policies in association with private capital, as highlighted by Gaspar (2010) and Almeida (2017).



Figure 4. Land use and land cover map of the Chapadinha microregion (year: 2009).

The pattern of agricultural expansion was defined as selective, predominantly in the east and center of the microregion, mainly in the municipalities of Brejo, Buriti, Anapurus, and Mata Roma.
The predominance is associated with geomorphological characteristics and the topographic profile (composition of tabular features with slope varying from flat to smooth) that enabled the implementation of modern agricultural practices and the use of fertilizers, resulting in significant agricultural advances. Araújo et al. (2019) emphasized that the municipality of Buriti presented $78 \%$ of new areas destined to agricultural production between 2000 and 2007. Almeida (2017) noted that the municipality of Brejo presented significant increase in areas for agricultural production between 2000 to 2015. When analyzing the vegetation cover conditions in the region, Silva et al. (2016) highlight the area has shown high rates of deforestation in recent decades.

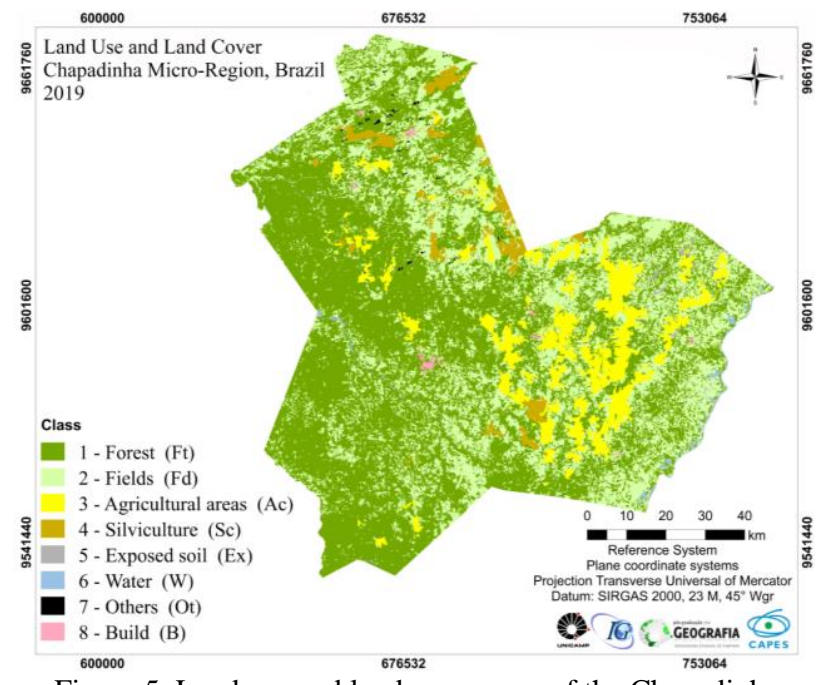

Figure 5. Land use and land cover map of the Chapadinha microregion (year: 2019).

\subsection{Detection of Change - 2000 to 2009}

Table 6 describes the areas occupied by each LULC classes, and the corresponding percentages of transitions that occurred in Chapadinha microregion between 2000 and 2009. The forest class showed significant reduction, approximately $7.13 \%$, or a total of $473 \mathrm{~km}^{2}$. The main conversions from forest areas were to fields, approximately $280 \mathrm{~km}^{2}$, agricultural areas $133 \mathrm{~km}^{2}$, and forestry $22 \mathrm{~km}^{2}$. The regeneration areas totalized approximately $773 \mathrm{~km}^{2}, 21 \%$ of which came from rural areas, $13 \%$ from exposed soil areas, and $38 \%$ expansion. It is worth noting that the class had a maintenance rate of $81 \%$, which indicates $5517.78 \mathrm{~km}^{2}$ of forest areas maintained between 2000 and 2009.

\begin{tabular}{|c|c|c|c|c|c|c|c|c|}
\hline \multirow{2}{*}{ Classes } & \multicolumn{7}{|c|}{2009} \\
\cline { 2 - 9 } & Fl & Fd & Ac & Sc & Ex & W & Ot & B \\
\hline Fl & 0.81 & 0.16 & 0.02 & 0.00 & 0.00 & 0.00 & 0.01 & 0.00 \\
\hline Fd & 0.21 & 0.59 & 0.14 & 0.01 & 0.02 & 0.00 & 0.01 & 0.00 \\
\hline Ac & 0.05 & 0.06 & 0.88 & 0.00 & 0.01 & 0.00 & 0.00 & 0.01 \\
\hline Sc & 0.15 & 0.03 & 0.00 & 0.82 & 0.00 & 0.00 & 0.00 & 0.00 \\
\hline Ex & 0.13 & 0.35 & 0.13 & 0.00 & 0.34 & 0.03 & 0.00 & 0.01 \\
\hline $\mathbf{W}$ & 0.09 & 0.11 & 0.00 & 0.00 & 0.04 & 0.75 & 0.01 & 0.00 \\
\hline Ot & 0.38 & 0.45 & 0.00 & 0.01 & 0.00 & 0.00 & 0.15 & 0.01 \\
\hline B & 0.04 & 0.13 & 0.03 & 0.00 & 0.01 & 0.01 & 0.00 & 0.78 \\
\hline
\end{tabular}

Table 6. Matrix of transition between 2000 to 2009 
Grasslands showed significant reduction in the analyzed period. This class represented $33 \%$ of the total area of the microregion in 2000. In 2019, it was reduced to $31 \%$. From 2000 to 2009 , the microregion lost approximately $7 \%$ of natural grasslands $(\sim 269$ $\left.\mathrm{km}^{2}\right)$. In the period analyzed, this class presented a preservation rate of $59 \%\left(2022.48 \mathrm{~km}^{2}\right)$. The main changes were for the forest class $(21 \%)$ and agricultural areas $(14 \%)$.

Bare soils showed an increase of $\sim 27 \%$ between 2000 and 2009. This increase reflects the agricultural expansion between 2000 and 2009. The expansion resulted in the new areas suppressed for crop plantation. Bare soil corresponds either to the areas prepared for plantation or to the areas in processes of loss of vegetation cover, without clear management.

The agricultural areas presented the highest percentage of increase between 2000 and 2009. In 2000, agricultural areas occupied less than $1 \%$ of the Chapadinha microregion, mainly related to agriculture of subsistence practiced by the local communities. In 2009, this class covered more than $6 \%$ of the total area. Agricultural areas showed significant increase (>800\%) from 2000 to 2009, going from $68 \mathrm{~km}^{2}$ to $664 \mathrm{~km}^{2}$ (Table 6). The main gains are associated with the conversion of rural areas $\left(\sim 453 \mathrm{~km}^{2}\right)$, and areas classified as bare soils (211 $\left.\mathrm{km}^{2}\right)$. The conversion of agricultural areas into other classes was low $(<10 \%)$.

Figure 6 shows the transition values between the LULC classes. Significant advance of agricultural areas and reduction of forest and grasslands was observed.

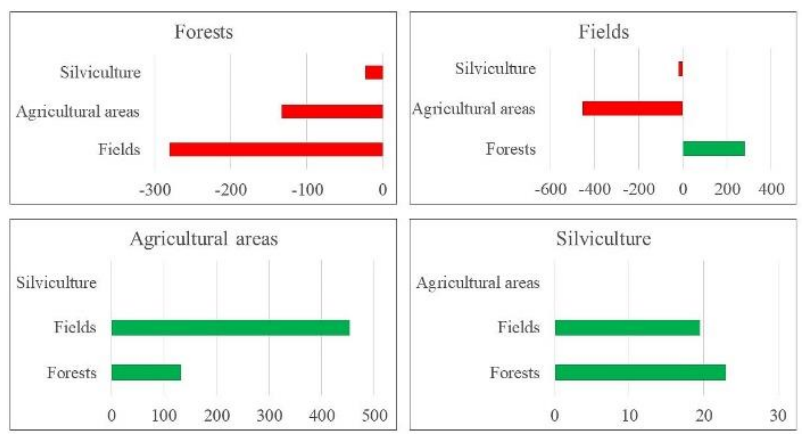

Figure 6. Transition of land use and land cover classes in the Chapadinha microregion (2000-2009 period).

\subsection{Change Detection - 2009 to 2019}

Between 2009 and 2019, the area faced a gradual change in terms of LULC classes (Table 7). Forests presented a constant rate of $74 \%\left(4857 \mathrm{~km}^{2}\right)$, with lower loss of forests to agriculture (conversion rate of $6.3 \%$ and a reduction of $390 \mathrm{~km}^{2}$ ). Forests lost $357.30 \mathrm{~km}^{2}$ for rural areas, $81 \mathrm{~km}^{2}$ for agriculture, and $38 \mathrm{~km}^{2}$ for silviculture. Regarding the regeneration, the rate reached $18 \%$, due to the recomposition of rural areas in new forested areas $\left(\sim 1061 \mathrm{~km}^{2}\right)$. Other classes accounted for 53\% of forest conversion rates.

The patterns of changes for rural areas showed a gradual increase in relation to $2009\left(\sim 134 \mathrm{~km}^{2}\right)$, representing an increase of $4 \%$ between 2009 and 2019. This class presented a gain rate of approximately $4 \%$, with the highest conversion of forest areas to grasses $\left(357 \mathrm{~km}^{2}\right)$. The conversion rates of grasslands to agriculture and silviculture were $154 \mathrm{~km}^{2}$ and $99 \mathrm{~km}^{2}$, respectively.

\begin{tabular}{|c|c|c|c|c|c|c|c|c|c|}
\hline \multirow{2}{*}{ Classes } & \multicolumn{8}{|c|}{2009} \\
\cline { 2 - 10 } & Fl & Fd & Ac & Sc & Ex & W & Ot & B \\
\hline Fl & 0.74 & 0.23 & 0.02 & 0.01 & 0.00 & 0.00 & 0.00 & 0.00 \\
\hline Fd & 0.34 & 0.54 & 0.07 & 0.03 & 0.00 & 0.00 & 0.00 & 0.00 \\
\hline Ac & 0.06 & 0.10 & 0.77 & 0.07 & 0.00 & 0.00 & 0.00 & 0.00 \\
\hline Sc & 0.08 & 0.12 & 0.00 & 0.79 & 0.00 & 0.00 & 0.00 & 0.00 \\
\hline Ex & 0.22 & 0.46 & 0.16 & 0.01 & 0.13 & 0.01 & 0.00 & 0.00 \\
\hline $\mathbf{W}$ & 0.26 & 0.13 & 0.01 & 0.00 & 0.04 & 0.55 & 0.00 & 0.00 \\
\hline Ot & 0.53 & 0.44 & 0.00 & 0.02 & 0.00 & 0.00 & 0.00 & 0.00 \\
\hline B & 0.12 & 0.13 & 0.01 & 0.00 & 0.01 & 0.00 & 0.00 & 0.72 \\
\hline
\end{tabular}

Table 7. Matrix of transition between 2009 to 2019 .

The advance of agriculture over natural areas was lower in approximately $1 \%$, as compared with that from 2000 to 2009 . Between 2009 and 2019, there was an 31\% increase. New agricultural areas increased $200 \mathrm{~km}^{2}$, mainly associated with the reuse of areas already destined for grain production. In this period, the main classes that showed conversion to agriculture were grasslands (7\%) and bare soils (17\%). These classes had a low conversion rate to other classes: $10 \%$ to rural areas and $6 \%$ to forest.

Forests showed a gradual growth, going from $24 \mathrm{~km}^{2}$ in 2000 to $67 \mathrm{~km}^{2}$ in 2009. Between 2009 and 2019, an increase of $187 \mathrm{~km}^{2}$ occurred, mainly in the northern portion of the microregion. The main classes converted for the implementation of silviculture were grasslands (3\%) and agricultural areas (7\%). About $12 \%$ of area occupied by silviculture were converted into grasslands, indicating a regeneration or Eucalyptus pruning for cellulose.

Figure 7 shows the conversion model of losses and gains between forest, grasslands, agricultural areas, and forestry classes from 2009 to 2019. The regeneration of rural areas was due to the abandonment of forest areas and the implementation of silviculture over the old agricultural areas.

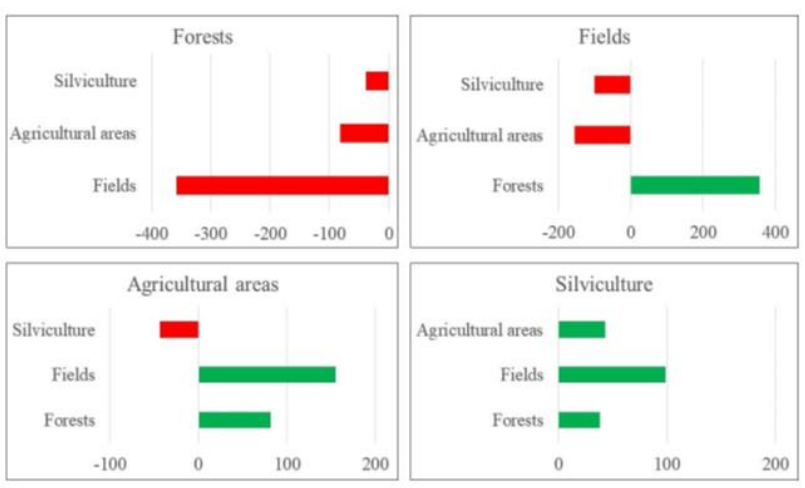

Figure 7. Transition of land use and land cover classes in the Chapadinha microregion (2009-2019 period).

Araújo et al. (2019), when analyzing land use by Landsat satellite images between 2000 and 2017, indicates that the region underwent intense environmental changes caused mainly by transformations in the land cover, these are directly related to the socioeconomic activities related to the insertion of the soybean monoculture. 


\section{CONCLUSIONS}

The use of Landsat images was essential to support the interpretation of the different types of LULC classes in the study area. It enabled the creation of an updated base of conversion and advance of soybean production in the area. The use of digital image processing techniques proved to be satisfactory to assess and analyze changes and to identify temporal changes at municipality level. The data survey of images and classifications and their insertion in a geographic database generated information about LULC changes. The object-oriented classification method was considered significant, as it allowed great automation of the mapping process and reduction in the efforts of manual editing's.

There was a $13 \%$ deforestation rate in the analyzed period, with high percentage associated with the insertion of annual crops. The agricultural area increased over $500 \mathrm{~km}^{2}$ between 2000 to 2019. Despite the high rate of deforestation, forest and countryside areas still represent the predominant land cover classes in the microregion. It represents approximately $88 \%$ of the land cover, mainly in the western and southern parts of the microregion, with emphasis to the municipalities of Chapadinha and Belágua that had a deforestation rate below 20\%. The municipalities of Brejo, Buriti, Anapurus, and Mata Roma presented deforestation rates higher than $45 \%$.

The data may serve as an instrument to elaborate protective environmental policies for the Cerrado at municipality level, as well as a management tool for public and private sectors.

\section{ACKNOWLEDGEMENTS}

This study was partially financed by the Coordination for the Improvement of Higher Education Personnel (CAPES - Finance Code 001) and by the National Council for Scientific and Technological Development (CNPq - Research Productivity Scholarship).

\section{REFERENCES}

Alencar, A., Shimbo, J., Lenti, F., Marques, C., Zimbres, B., Rosa, M., Arruda, V., Castro, I., Ribeiro, J., Varela, V., Alencar, I., Piontekowski, V., Ribeiro, V., Bustamante, M., Sano, E., Barroso, M., 2020. Mapping Three Decades of Changes in the Brazilian Savanna Native Vegetation Using Landsat Data Processed in the Google Earth Engine Platform. Remote Sensing, 12(6), 924-947. doi.org/10.3390/rs12060924

Almeida, J. G., 2017. A luta na/pela terra frente à expansão da soja no município de Brejo - MA. Dissertação de Mestrado em Geografia, Natureza e Dinâmica do Espaço, Universidade Estadual do Maranhão, MA, Brasil.

Arantes, A., Ferreira, L., Coe, M., 2016. The seasonal carbon and water balances of the Cerrado environment of Brazil: past, resent, and future influences of land cover and land use. ISPRS $J$. Photogramm. Remote Sensing, 117(7), 66-78. doi.org/10.1016/j.isprsjprs.2016.02.008

Araújo, H., Pereira, P., Rodrigues, T., Costa Jr., E., 2019. Mudança de cobertura da terra nos municípios de chapadinha e buriti, MA, entre os anos de 1990 a 2017. Revista Geonorte, 10(36), 194-214. doi.org/10.21170/geonorte.2019.V.10.N.36.A194.214
Baatz, M., Schape, A., 2000. Multiresolution Segmentation. Angewandte Geographische Informationsverarbeitung, 12, 1223.

Batistella, M., Bolfe, E., Vicente. L., Victoria, D., Araújo, L., 2013. Relatório do Macrozoneamento do Maranhão, MA, Brasil. ainfo.cnptia.embrapa.br/digital/bitstream/item/103356/1/Relator ioDiagnostico-Prod3-Vol2-MacroZEE.pdf (10 January 2020).

Bendini, H., Sanches, I., Korting, T., Fonseca, L., Luiz, A., Formaggio, A., 2016. Using Landsat 8 image time series for crop mapping in a region of cerrado, Brazil. ISPRS Ann. Photogramm. Remote Sens. Spatial Inf. Sci., XLI-B8, 845-850. doi.org/10.5194/isprs-archives-XLI-B8-845-2016

Benz, U. C., Hofmann, P., Willhauck, G., Lingenfelder, I., Heynen, M., 2004. Multi-re-solution, object-oriented fuzzy analysis of remote sensing data for GIS-ready in-formation. ISPRS J. Photogramm. Remote Sensing, 58 (3-4), 239-258. doi.org/10.1016/j.isprsjprs.2003.10.002

Bolfe, E., Victoria, D., Contini, E., Bayma-Silva, G., SpinelliAraujo, L. Gomes, D., 2016. Matopiba em crescimento agrícola. Revista de Política Agrícola, 25(4), 38-62. seer.sede.embrapa.br/index.php/RPA/article/view/1202

Camargo, F., Sano, E., Almeida, C., Mura, J., Almeida, T., 2019. A comparative assessment of machine-learning techniques for land use and land cover classification of the Brazilian tropical savanna using ALOS-2/PALSAR-2 polarimetric images. Remote Sensing, 11(13), 1600-1616. doi.org/10.3390/rs11131600

Campos, M., 2011. O papel do estado brasileiro na expansão do complexo da soja. Anais do XII Colóquio Int. de Geocrítica: Bogotá, 1-17.

Chavez, J., 1988. An improved dark-object subtraction technique for atmospheric scattering correction of multispectral data. Remote Sensing of Environment, 24(3), 459-479. doi.org/10.1016/0034-4257(88)90019-3

Congedo, L., 2016. Semi-Automatic Classification Plugin Documentation. Technical Report - GIS to Remote Sensing. doi.org/10.13140/RG.2.2.29474.02242/1

Gaspar, R., 2010. O eldorado dos gaúchos: deslocamento de agricultores do Sul do país e seu estabelecimento no Leste Maranhense. Dissertação de Mestrado em Ciências Sociais, Universidade Federal do Maranhão, MA, Brasil.

Guimarães, A., 2012. Dinâmica agrícola da soja no cerrado da microrregião de Chapadinha-MA. Dissertação de Mestrado em Desenvolvimento Socioespacial e Regional, Universidade Estadual do Maranhão, MA, Brasil.

IBGE. Instituto Brasileiro de Geografia e Estatística, 2009. Manual Técnico de Uso da Terra. Rio de Janeiro, Brasil. biblioteca.Ibge.gov.br/visualizacao/livros/liv81615.pdf November 2019)

IBGE. Instituto Brasileiro de Geografia e Estatística, 2019. Estatísticas Sociais, Econômicas e Produção Agrícola Municipal (2000, 2009 e 2019). sidra.Ibge.gov.br/pesquisa/pam/tabelas (25 August 2019). 
Inocêncio, M., Calaça, M., 2009. Cerrado: Fronteira da produção agrícola capitalista do século XX. XIX Encontro Nacional de Geografia Agrária, 1-16.

INPE. Instituto Nacional de Pesquisas Espaciais, 2017. TerraView software. dpi.inpe.br/terraview (25 November 2019)

Klink, C., Machado, R., 2005. Conservation of the Brazilian Cerrado. Conservation Biology, 19(3), 707 - 713. doi.org/10.1111/j.1523-1739.2005.00702.x

Korting, T., Fonseca, L., Escada, M., Câmara, G., 2009. GeoDMA: Um sistema para mineração de dados de sensoriamento remoto. Anais do XIV Simpósio Brasileiro de Sensoriamento Remoto, Natal, Brasil. 7813-7820.

Landis, J., Koch, G., 1977. An application of hierarchical kappatype statistics in the assessment of majority agreement among multiple observers. Biometrics, 33(2), 363-74. doi.org/10.2307/2529786

Meneses, P., Almeida, T., 2012. Introdução ao Processamento de Imagens de Sensoriamento Remoto. Universidade de Brasília, DF, Brasil. 266 p.

MMA. Ministério do Meio Ambiente, 2015. O Bioma Cerrado. mma.gov.br/biomas/cerrado (22 January 2020)

Picoli, M., Câmara, G., Sanches, I., Simões, R. Carvalho, A., Maciel, A., Coutinho, A., Esquerdo, J., Antunes, J., Begotti, R., Arvor, D., Almeida. C., 2018. Big earth observation time series analysis for monitoring Brazilian agriculture. ISPRS Journal of Photogrammetry and Remote Sensing. 145(b), 328-339. doi.org/10.1016/j.isprsjprs.2018.08.007

Ponzoni, F., Shimabukuro, Y., 2009. Sensoriamento Remoto no estudo da vegetação. SP: Parênteses.120p.

Reschke, G., Eloi. C., Silva. R., 2011. Caracterização climática da amazônia maranhense. In: Maerins. M., Oliveira. T. Amazônia Maranhense: diversidade e conservação. Belém, PA, Brasil. 329 p.

Rosa, R., 2009. Introdução ao Sensoriamento Remoto. MG: Edufu. 260p.

Sano, E., Rosa, R., Brito, J., Ferreira, L., Bezerra, H. 2009. Mapeamento da cobertura vegetal natural e antrópica do bioma Cerrado por meio de imagens Landsat ETM+. Anais do XIV Simpósio Brasileiro de Sensoriamento Remoto, Natal, Brasil. 1199-1206.

Sano, E., Rosa, R., Scaramuzza, C., Adami, M., Bolfe, E., Coutinho, A., Esquerdo, J., Maurano, L., Narvaes, I., Oliveira Filho, F., Silva, E. Victoria, D., Ferreira, L., Brito, J. , Bayma, A., Oliveira, G., Silva, G., 2019a. Land use dynamics in the Brazilian Cerrado in the period from 2002 to 2013. Pesquisa Agropecuária Brasileira, 54(2), 1-5. doi.org/10.1590/s16783921.pab2019.v54.00138

Sano, E., Ponzoni, F., Meneses, P., Baptista, G., Toniol, A., Galvão, L., Rocha, W., 2019b. Reflectância da vegetação. In: Meneses, P., Almeida, T., Baptista, G. (Org.). Reflectância dos Materiais Terrestres. Análise e Interpretação. Oficina de Textos, SP, Brasil, 189-223.
Santos, T., 2011. A Expansão da fronteira agrícola em Balsas, MA. Tese de Doutorado em Ciências Ambientais, Universidade Federal de Goiás, GO, Brasil.

Silva, J., Silva, E., Ferreira, P., Gomes, V., Barboza, K., Candeias, A., 2016. Spatial-temporal evolution analysis of the vegetation in the Chapadinha microregion (Maranhão, Brazil) through remote sensing. Journal of Hyperspectral Remote Sensing, 6(6), 329-337. periodicos.ufpe.br/revistas/jhrs/article/view/22760

USGS. United States Geological Survey, 2020. Earth explorer platform. earthexplorer.usgs.gov (25 November 2019)

Zanotta, D., Ferreira, M., Zortea, M. 2019. Processamento Digital de imagens. Oficina de Textos, SP, Brasil. 320p. 